\begin{tabular}{|l|l|l||}
\hline \multicolumn{2}{|c|}{ PublisherInfo } \\
\hline \hline PublisherName & $:$ & BioMed Central \\
\hline \hline PublisherLocation & $:$ & London \\
\hline \hline PublisherImprintName & $:$ & BioMed Central \\
\hline \hline
\end{tabular}

\title{
Breast cancer prognosis
}

\begin{tabular}{|l|c|l||}
\hline \multicolumn{2}{|c|}{ ArticleInfo } \\
\hline \hline ArticleID & $:$ & 4391 \\
\hline \hline ArticleDOI & $:$ & $10.1186 /$ gb-spotlight-20020204-01 \\
\hline \hline ArticleCitationID & $:$ & spotlight-20020204-01 \\
\hline \hline ArticleSequenceNumber & $:$ & 57 \\
\hline \hline ArticleCategory & $:$ & Research news \\
\hline ArticleFirstPage & $:$ & 1 \\
\hline \hline ArticleLastPage & $:$ & 2 \\
\hline \hline & & RegistrationDate : 2002-2-4 \\
\hline ArticleHistory & $:$ & OnlineDate \\
\hline \hline ArticleCopyright & $:$ & BioMed Central Ltd2002-2-4 \\
\hline \hline ArticleGrants & $:$ & \\
\hline \hline ArticleContext & $:$ & 130593311 \\
\hline \hline
\end{tabular}




\section{Jonathan B Weitzman}

Email: jonathanweitzman@hotmail.com

No-one really understands why some women with breast cancer respond well to chemotherapy while others do not, or how to predict an individual patient's chances of survival. In the January 31 Nature, Laura van't Veer and colleagues describe a gene-expression profiling study of breast tumours (Nature 2002, 415:530-536). They chose around 100 primary breast cancers (with and without metastases or $B R C A 1$ mutations) and looked at the relative expression levels of 25,000 genes. They used a three-step supervised classification method to distinguish groups of tumours with good or poor prognosis. An expression signature panelof 70 genes could accurately predict 'poor prognosis' patients. This set includes genes encoding proteins involved in cell invasion, metastasis and angiogenesis. Women under 55 who are diagnosed with lymph-node-negative breast cancer have a 28 -fold higher chance of developing distant metastases within 5 years if they have a 'poor prognosis signature' rather than a 'good prognosis signature'. This predictor is better than current clinical and histopathological prognostic factors, and may help to improve the criteria for selecting patients for adjuvant therapy.

\section{References}

1. Prognostic indicators in early breast cancer.

2. Nature, [http://www.nature.com]

3. Classification and diagnostic prediction of cancers using gene expression profiling and artificial neural networks.

4. Gene expression profiling predicts clinical outcome of breast cancer., [http://www.rii.com/ publications/default.htm] 